\title{
Development of High Speed Submerged Arc Welding in Spiral Pipe Mill*
}

\author{
By Mitsuhiro HANADA, ,* Hiromitsu TAKEDA, ,** Hisafumi FUKUSHIMA,** \\ Isamu KOIZUMI**** and Yoshiaki NOGUCHI*****
}

\section{Synopsis}

The studies were carried out to increase welding speed in the spiral pipe mill. The problems which prevent the increase of the welding speed are the occurrence of undercut, concave bead, convex bead.

Investigations were carried out to solve these problems. Main results obtained are as follows;

(1) The optimum welding conditions, for the high speed welding were found.

(2) The good bead appearance could be obtained by the use of the new flux bearing optimum amount of titanium dioxide.

\section{Introduction}

Spiral pipe was produced for the first time in 1877. The process of producing spiral pipe has been progressively developed, so that today large diameter spiral pipe can be economically produced. These pipes are used for line pipe for transmission of fluids such as gases and water, for foundation piles and other structural pipes.

Up to the present, many efforts which enable increased productivity have been carried out in the world. It is the most effective method to increase productivity that welding speed is made high.

In the conventional process pipes are welded from both inside and outside by tandem submerged-arc units in the forming machine. In this process, there are many problems which prevent the increase of the welding speed. Studies were carried out to solve these problems.

\section{Characteristics of Weld Shape of Spiral Pipe}

The process for spiral pipe is illustrated in Fig. 1.

The pipes are simultaneously welded from inside and outside by tandem submerged arc units at the positions as shown in Fig. 2. The inclination at the welding position and flowing of weld metal during solidification characterize the weld shape as follows.

\section{Weld Shape of Inside Welding}

The inside welding head is positioned before the 6 o'clock as shown in Fig. 2, therefore the slope of weld is ascent under the head. However, the slope of weld at the point where the solidification of weld metal is finished becomes descent by rotation of the pipe. For this reason, inside weld shows the shape dented at the center of the bead section, called as a concave bead.

\section{Weld Shape of Outside Welding}

On the other hand, as the outside welding head is positioned before the 12 o'clock as shown in Fig. 2, the slope of weld under the head is descent, and becomes ascent at the point where the solidification of weld metal is finished. Because of the flowing forward of weld metal, the outside weld shape is upheaved at the center of the bead section as shown in Fig. 2, called as a convex bead.

The degrees of the concave and convex are in-

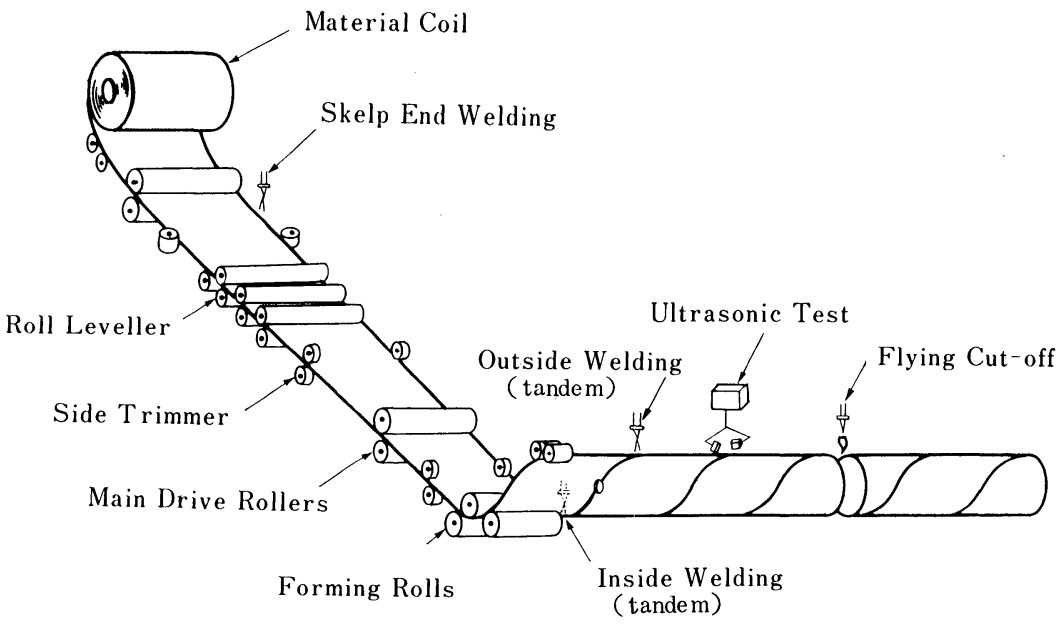

Fig. 1. Schematic illustration of spiral pipe process.

\footnotetext{
* Originally published in Sumitomo Metals, 34 (1982), No. 2, 51, in Japanese. English version received on August 13, 1985; accepted in the final form on November 1, 1985. (C) 1986 ISIJ

** Kashima Works, Sumikin Weld Pipe, Ltd., Higashi-Fukashiba, Kamisu-cho, Kashima-gun, Ibaraki 314-02.

*** Sakai Works, Sumikin Weld Pipe, Ltd., Dezima-Nishimachi, Sakai 590.

**** Steel Plate Technology Department, Sumitomo Metal Industries, Ltd., Otemachi, Chiyoda-ku, Tokyo 100.

***** Technical Department, Amagasaki Plant, Sumikin Welding Industries, Ltd., Fuso-cho, Amagasaki 660.
} 

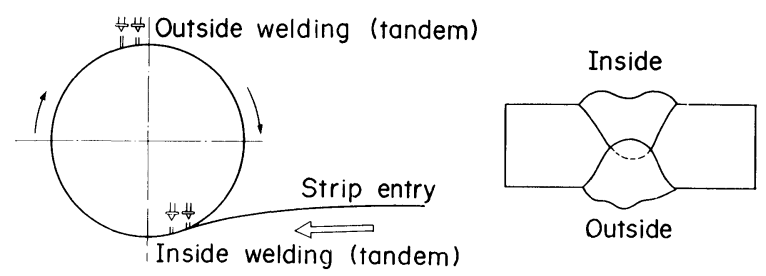

Fig. 2. Figure of welding position and weld shape.

fluenced by the electrode position, welding condition (welding speed, current, voltage), and the flux.

\section{Factors Affecting Welding Speed}

Figure 3 shows the factors affecting the welding speed and the countermeasures for high speed welding.

Figure 4 shows the change of the weld shape by increase of the welding speed.

From Fig. 3, we investigated the following items;

1) stabilization of welding arc by improving the power source

2) study of optimum welding condition

3) development of flux for high speed welding.

In this report, the results of the items 2) and 3) are described.

\section{Study of Welding Condition for High Speed Welding $(I)$}

In the tandem spiral welding process, it is well known that the welding parameters such as the welding current and the arc voltage at the leading wire and trail wire influence the weld geometry. Then, each parameter was varied individually to study its influence on weld bead appearance and to obtain the optimum welding condition.

Experiments were performed by welding inside of the test pipe by use of the spiral welding test equipment. Materials in these experiments are listed in Table 1, and welding conditions are shown in Table 2. The welding speed was set to $3500 \mathrm{~mm} / \mathrm{min}$ as aimed welding speed which is about 1.4 times of usual welding speed. Median value of current at the leading wire was set to $1250 \mathrm{~A}$ to obtain about $60 \%$ penetration of the plate thickness on referring by following equation. ${ }^{1)}$

$$
P=K\left(0.109 I_{1} / \sqrt{V \times 10^{2}}-0.19 V_{1}+5.03\right)
$$

where, $K=0.01 t+0.79$

$P$ : Penetration ( $\mathrm{mm})$

$I_{1}$ : Current of leading wire (A)

$V_{1}$ : Voltage of leading wire (V)

$V$ : Welding speed $(\mathrm{mm} / \mathrm{min})$

$t$ : Thickness of pipe (mm).

The experimental results are shown in Fig. 5 . It was found that good bead appearance could be obtained by choice of welding condition as shown in Table 3 in spite of high speed welding.

However, as shown in Fig. 6, the range in which the good weld shape can be obtained is very narrow.

Therefore, in actual spiral mills, it seemed hard to weld in high speed only by controlling these welding

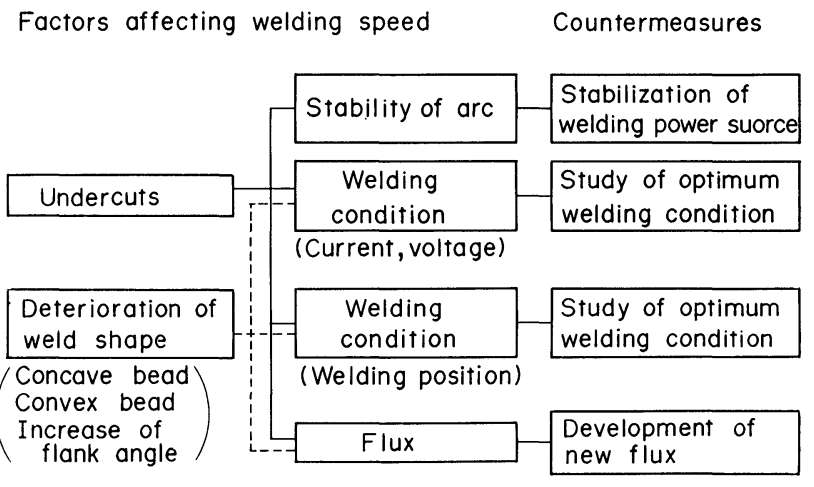

Fig. 3. Factors affecting welding speed and countermeasures.

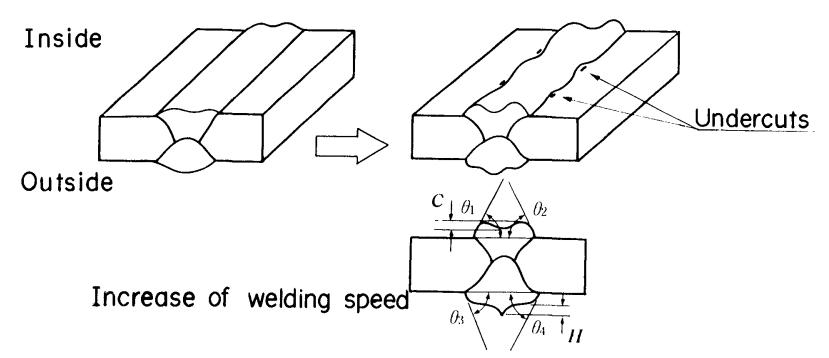

$C$ : Concave height (Inside welding)

$H$ : Upheaved height (Outside welding) $\theta_{1} \sim \theta_{4}: \quad$ Flank angle

Fig. 4. Change of weld shape by increase of welding speed.

Table 1. Materials.

\begin{tabular}{l|l} 
Test pipe & $800 \mathrm{~mm}$ O.D. $\times 9 \mathrm{~mm} \mathrm{W.T.} \times 3000 \mathrm{~mm} \mathrm{~L}$ \\
Electrode size & $4.8 \mathrm{~mm}, 4.0 \mathrm{~mm}$ \\
Flux & $\mathrm{S} 1(12 \times 65 \mathrm{mesh})$
\end{tabular}

Table 2. Welding conditions.

\begin{tabular}{|c|c|c|c|c|c|}
\hline & \multicolumn{2}{|c|}{ Lead (DG) } & \multicolumn{2}{|c|}{ Trail (AG) } & \multirow{2}{*}{$\begin{array}{l}\text { Welding } \\
\text { speed } \\
(\mathrm{mm} / \mathrm{min})\end{array}$} \\
\hline & $\begin{array}{l}\text { Current } \\
\text { (A) }\end{array}$ & $\begin{array}{c}\text { Voltage } \\
\text { (V) }\end{array}$ & $\begin{array}{l}\text { Current } \\
\text { (A) }\end{array}$ & $\begin{array}{c}\text { Voltage } \\
\text { (V) }\end{array}$ & \\
\hline (1) & 1250 & $V_{1}$ & 740 & 33 & 3500 \\
\hline (2) & $I_{1}$ & 28 & 740 & 33 & 3500 \\
\hline (3) & 1250 & 28 & 680 & $V_{2}$ & 3500 \\
\hline (4) & 1250 & 28 & $I_{2}$ & 33 & 3500 \\
\hline
\end{tabular}

$I_{1}, I_{2}, V_{1}, V_{2}:$ variable

parameters, and it was necessary to develop a new flux for high speed welding.

\section{Development of Flux for High Speed Welding}

It is well known that the weld geometry is influenced greatly by the chemical composition and the mesh size of the flux. Especially, in spiral welding process in which the weld metal flow by the gravity during its solidification, the choice of the welding flux is one of the most important factors influencing the weld shape. 

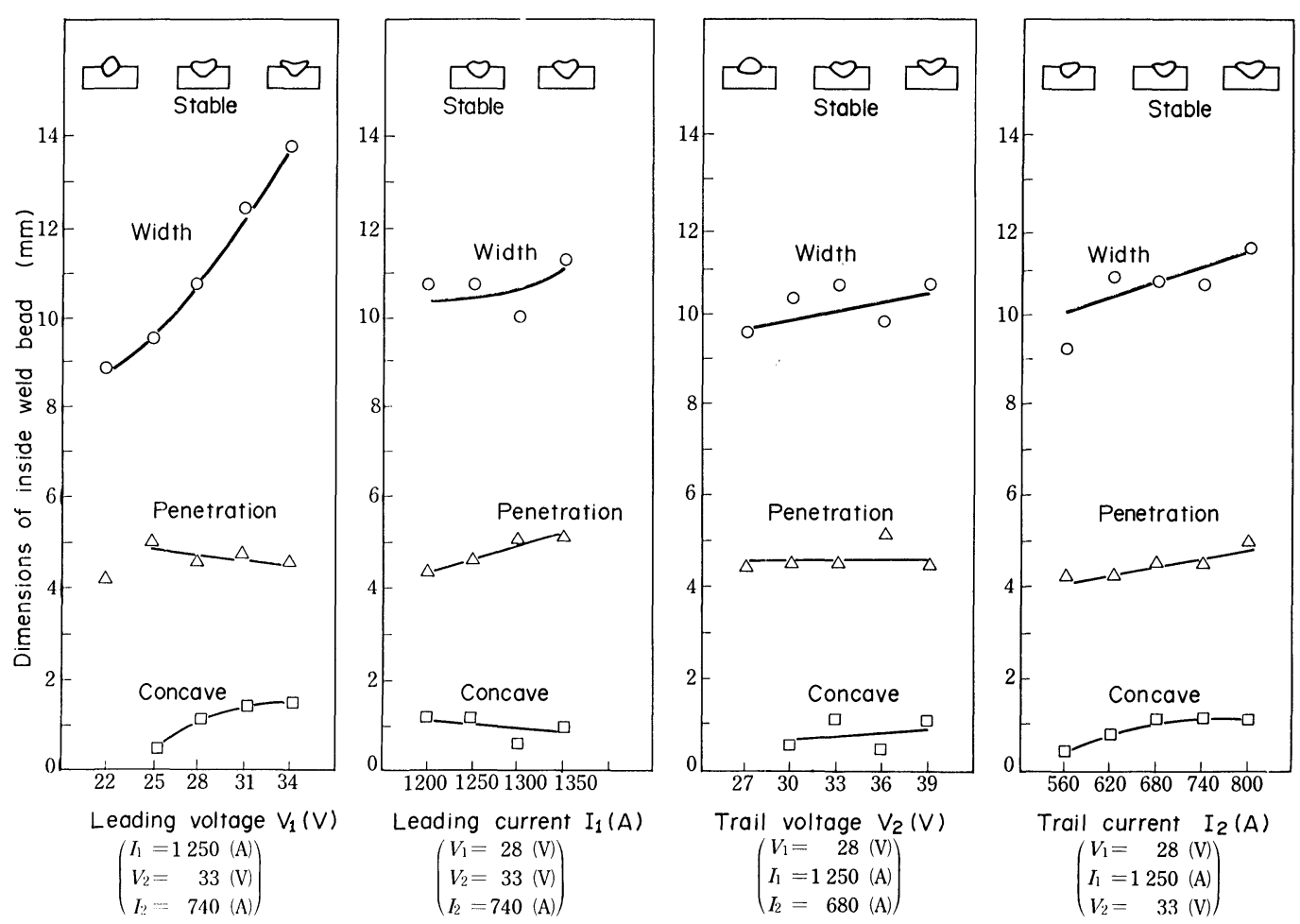

Fig. 5. Effect of welding parameter on the weld shape.
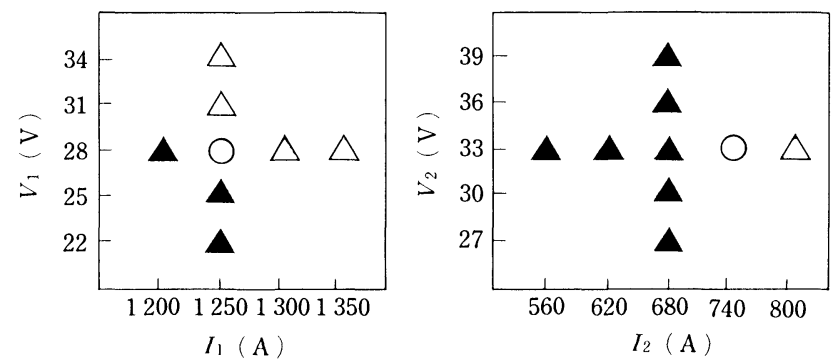

O: Optimum condition

$\Delta:$ Free from undercut fluctuation of bead width concave bead

$\Delta$ : Occurrence of undercuts

Fig. 6. Range of optimum condition for high speed welding.

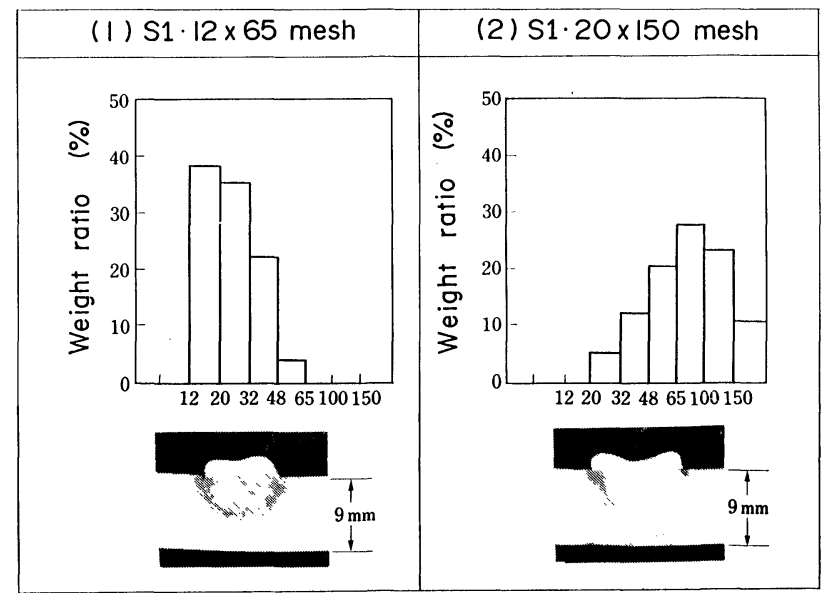

Fig. 7. Effect of mesh size of flux on weld shape.

Table 3. Optimum welding condition for high speed welding.

\begin{tabular}{|c|c|c|c|c|}
\hline \multicolumn{2}{|c|}{ Leading (DC) } & \multicolumn{2}{|c|}{ Trail (AC) } & \multirow{2}{*}{$\begin{array}{l}\text { Welding } \\
\text { speed } \\
(\mathrm{mm} / \mathrm{min})\end{array}$} \\
\hline $\begin{array}{l}\text { Current } \\
\text { (A) }\end{array}$ & $\begin{array}{l}\text { Voltage } \\
\text { (V) }\end{array}$ & $\begin{array}{l}\text { Current } \\
\text { (A) }\end{array}$ & $\begin{array}{c}\text { Voltage } \\
(\mathrm{V})\end{array}$ & \\
\hline 1250 & 28 & 740 & 33 & 3500 \\
\hline
\end{tabular}

The main items of flux properties affecting on the shape of welds are as follows;

1) mesh size

2) melting point

3) viscosity at high temperature.

Experiments were performed to study the effects of mesh size and chemical composition of flux on the weld shape.

Table 4. Welding condition for flux test.

\begin{tabular}{|c|c|c|c|c|}
\hline \multicolumn{2}{|c|}{ Leading (DC) } & \multicolumn{2}{|c|}{ Trail (AG) } & \multirow{2}{*}{$\begin{array}{l}\text { Welding } \\
\text { speed } \\
(\mathrm{mm} / \mathrm{min})\end{array}$} \\
\hline $\begin{array}{l}\text { Current } \\
\text { (A) }\end{array}$ & $\begin{array}{c}\text { Voltage } \\
\text { (V) }\end{array}$ & $\begin{array}{l}\text { Gurrent } \\
\text { (A) }\end{array}$ & $\begin{array}{c}\text { Voltage } \\
\text { (V) }\end{array}$ & \\
\hline 1250 & 28 & 680 & 33 & 3500 \\
\hline
\end{tabular}

\section{Study on Mesh Size of Flux}

Figure 7 shows the effect of the mesh size of the flux on the weld shape welded under the condition shown in Table 4. It was found from Fig. 7 that width of weld was extended and undercut tendency was greatly reduced by the use of finer mesh size flux.

It is considered that this reduction of undercut 
tendency with fining of the mesh size was caused by the decrease of the arc atmospheric pressure and the reduction in the fluctuation of arc pressure by the fining of the mesh size.

\section{Study on Chemical Composition of Flux}

The study on the chemical composition of flux was carried out. Four trial fluxes were made by adding an oxide such as $\mathrm{TiO}_{2}, \mathrm{ZrO}_{2}, \mathrm{BaO}$, and so on to flux S1 of standard flux.

Table 5 shows the trial fluxes.

Photograph 1 shows the shapes of the welds by use of these trial fluxes. Materials used in this experiment are listed in Table 6 , and the welding condition is shown in Table 7.

It was found from the weld shapes by flux $\mathrm{A}$ and flux $\mathrm{B}$ that the addition of $\mathrm{TiO}_{2}$ extended the width of weld bead and reduced the concave tendency. Furthermore $\mathrm{TiO}_{2}$ had the effect arresting undercut.

Table 5. Trial fluxes.

\begin{tabular}{l|l} 
Sl & Standard flux $\left(\mathrm{SiO}_{2}-\mathrm{MnO}-\mathrm{CaO}\right.$ system $)$ \\
A & $\mathrm{TiO}_{2}$ added \\
B & $\mathrm{TiO}_{2}$ added \\
$\mathrm{C}$ & $\mathrm{BaO}$ added \\
$\mathrm{D}$ & $\mathrm{ZrO}$ added \\
\hline
\end{tabular}

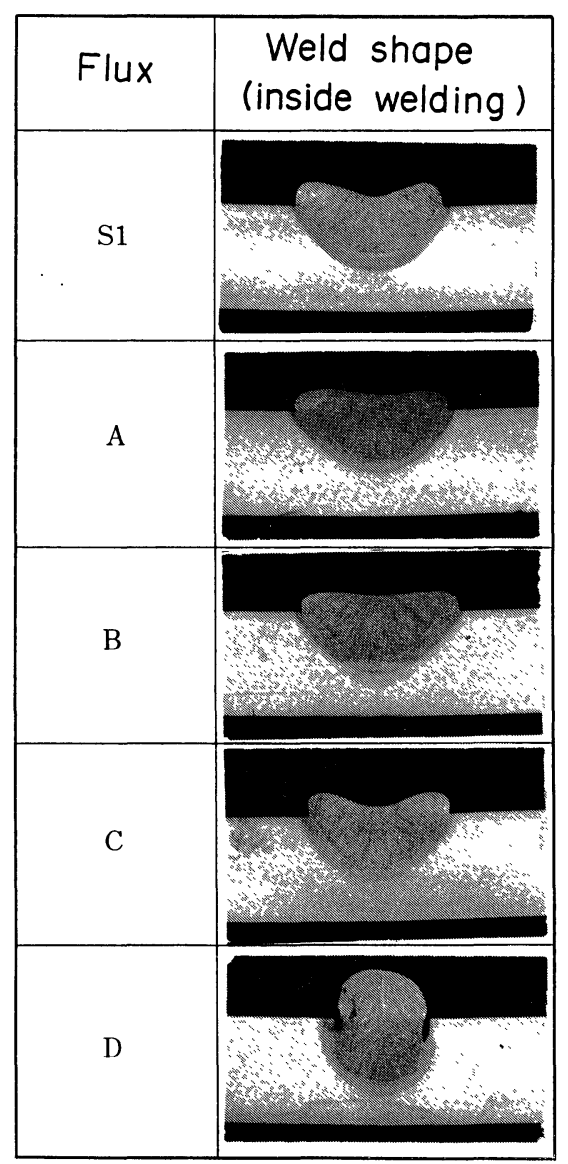

Photo. 1. Effect of chemical composition of flux on the weld shape.
In the trial fluxes, flux B was seemed to be most suitable for high speed welding.

Figure 8 shows the result of "button test" in which the melting points of fluxes are compared with each other and that the melting point of flux B is higher than that of flux S1. Figure 9 shows the effect

Table 6. Materials for flux test.

\begin{tabular}{l|l} 
Tets pipe & $800 \mathrm{~mm}$ O.D. $\times 9 \mathrm{~mm} \mathrm{W.T.} \times 3000 \mathrm{~mm} \mathrm{~L}$ \\
Electrode size & $4.8 \mathrm{~mm}, 40 \mathrm{~mm}$
\end{tabular}

Table 7. Welding condition for flux test.

\begin{tabular}{l|c|c|c}
\hline & $\begin{array}{c}\text { Current } \\
(\mathrm{A})\end{array}$ & $\begin{array}{c}\text { Voltage } \\
(\mathrm{V})\end{array}$ & $\begin{array}{c}\text { Welding speed } \\
(\mathrm{mm} / \mathrm{min})\end{array}$ \\
\hline Leading & 1200 & 28 & 3200 \\
Trail & 720 & 34 & \\
\hline
\end{tabular}

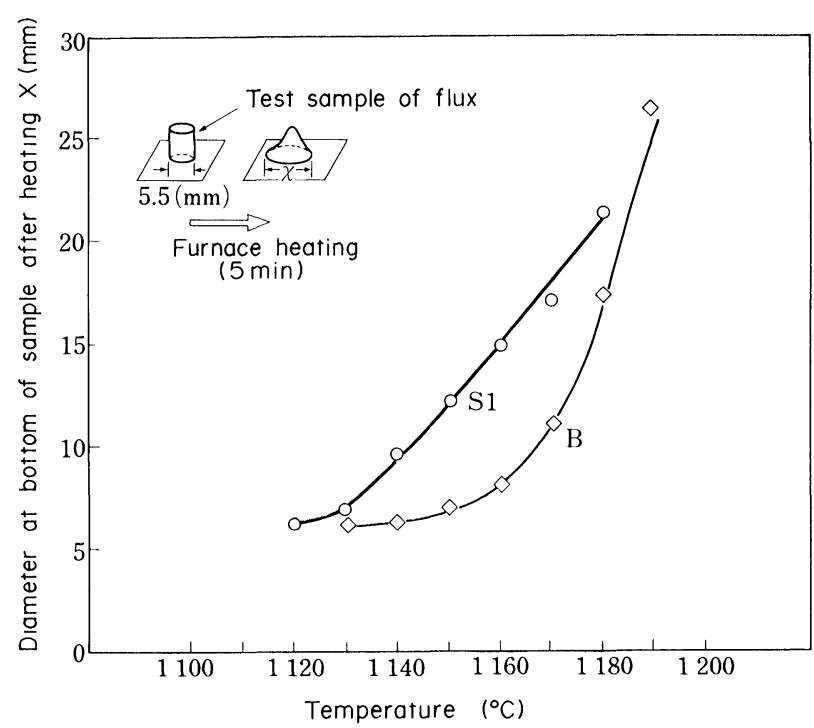

Fig. 8. Result of button test.

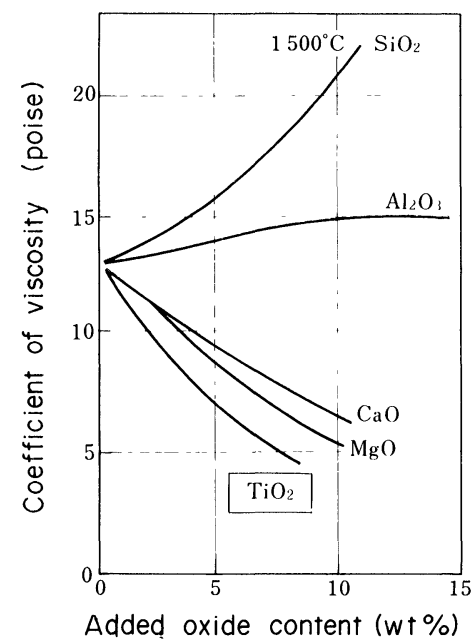

Fig. 9. Effect of added oxide on viscosity of $\mathrm{CaO}-\mathrm{SiO}_{2}-$ $\mathrm{Al}_{2} \mathrm{O}_{3}$ system slag. 
of added oxide on viscosities of slags. ${ }^{2}$ With increase of $\mathrm{TiO}_{2}$ content, the viscosity of slag is decreased.

From the results mentioned above, the properties of the flux required for high speed welding in spiral welding may be shown below.

1) fine mesh size

2) high melting point

3) low viscosity of slag.

Figure 10 shows the fluctuation of arc voltage of the trail wire welded with flux $\mathrm{B}$ in comparison with flux S1.

In the case of flux $\mathrm{B}$, the reignition voltage is lower and the fluctuation of arc voltage is less than the case of flux $\mathrm{S} 1$.

From the results mentioned above, flux B was chosen for high speed welding in spiral welding process.

\section{Study of Welding Condition for High Speed Welding $(I I)$}

As mentioned before, the pos tion of the electrodes is an important factor influencing the weld shape.

Before the on-line test with flux $\mathrm{B}$, the influence of the leading electrode position $(L)$ and the spacing between the leading and trail wires $(I)$, as shown in Fig. 11, was investigated.

Materials used in this experiment is listed in Table 8 and the welding condition is shown in Table 9. Flux B was used for this experiment. Figure 12 shows the influence of the leading electrode position $(L)$ on the weld shape. Figure 13 shows the influence of the electrode spacing $(I)$ on the weld shape.

The weld shapes were varied by changing the leading electrode position $(L)$ and the spacing between the leading and trail wires $(I)$. The good weld shape could be obtained in the range of $(L)$ from 0 to $20 \mathrm{~mm}$ and in the range of $(I)$ from 14 to $18 \mathrm{~mm}$.

\section{Application of High Speed Welding in Actual Spiral Pipe Mill}

Based on the results obtained in the previous experiments, the high speed welding tests in actual manufacturing line were carried out on several occasions with flux B. In these high speed welding tests, good bead appearances were obtained through

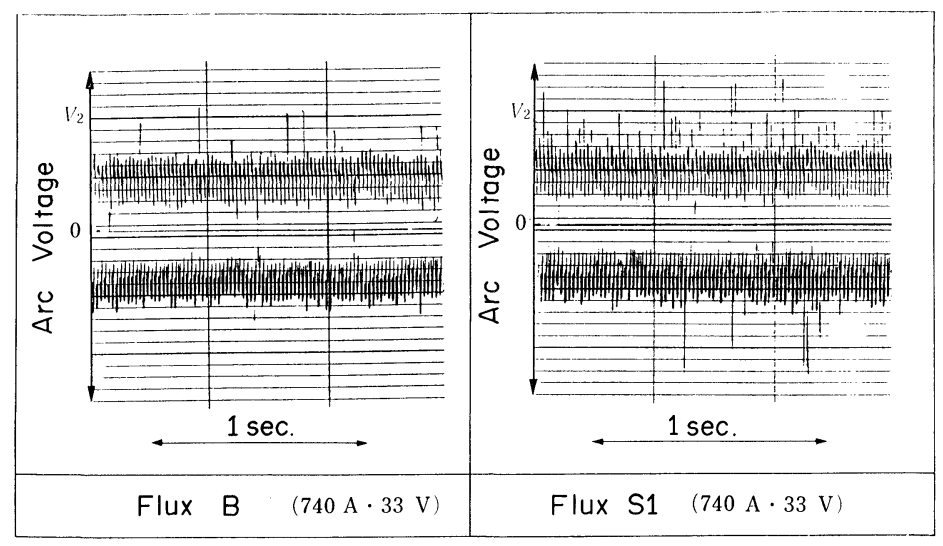

Fig. 10. Comparison for arc voltage of flux B and flux S1.
Table 8. Materials for welding position test.

Test pipe

Electrode size

$800 \mathrm{~mm}$ O.D. $\times 9 \mathrm{~mm}$ W.T. $\times 3000 \mathrm{~mm} \mathrm{~L}$

Flux

$4.8 \mathrm{~mm}, 4.0 \mathrm{~mm}$

Flux $\mathrm{B}(20 \times 150$ mesh $)$

Table 9. Welding condition for welding position test.

\begin{tabular}{|c|c|c|c|c|}
\hline \multicolumn{2}{|c|}{ Leading } & \multicolumn{2}{|c|}{ Trail } & \multirow{2}{*}{$\begin{array}{l}\text { Welding } \\
\text { speed } \\
(\mathrm{mm} / \mathrm{min})\end{array}$} \\
\hline $\begin{array}{l}\text { Current } \\
\text { (A) }\end{array}$ & $\begin{array}{c}\text { Voltage } \\
\text { (V) }\end{array}$ & $\begin{array}{l}\text { Current } \\
\text { (A) }\end{array}$ & $\begin{array}{c}\text { Voltage } \\
\text { (V) }\end{array}$ & \\
\hline 1250 & 23 & 740 & 33 & 3500 \\
\hline
\end{tabular}

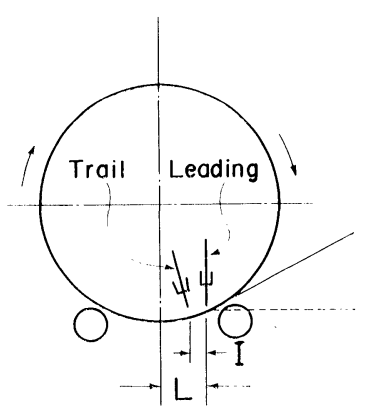

$L$ : Position of leading electrode

I: $\quad$ spacing between electrodes

Fig. 11. Welding position.

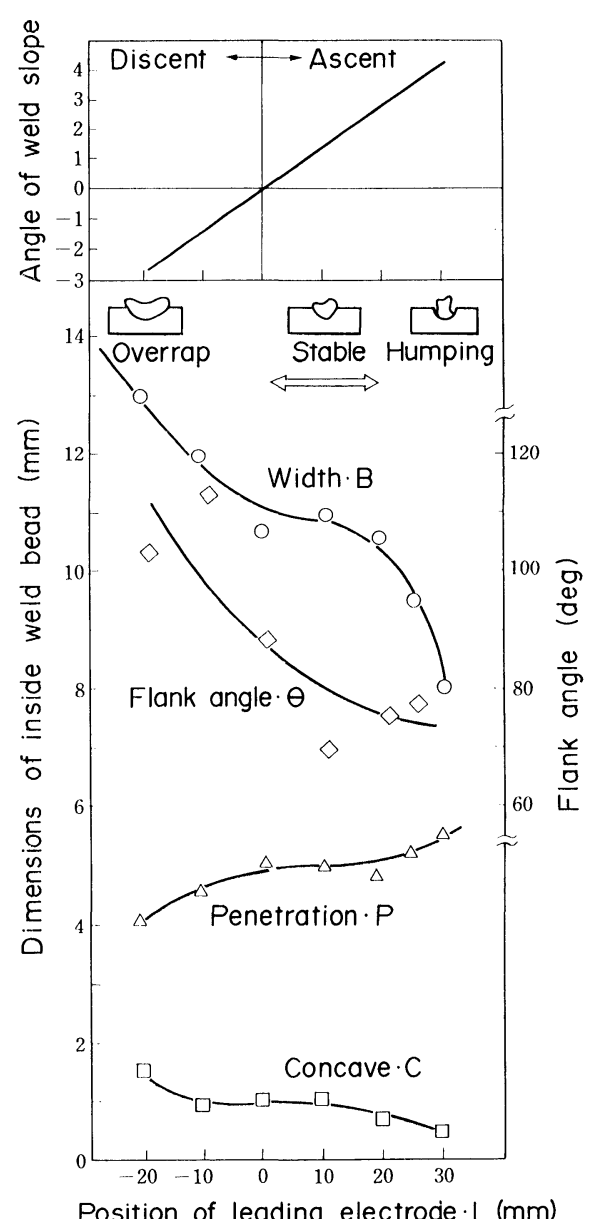

Fig. 12. Effect of leading electrode position on weld shape. 

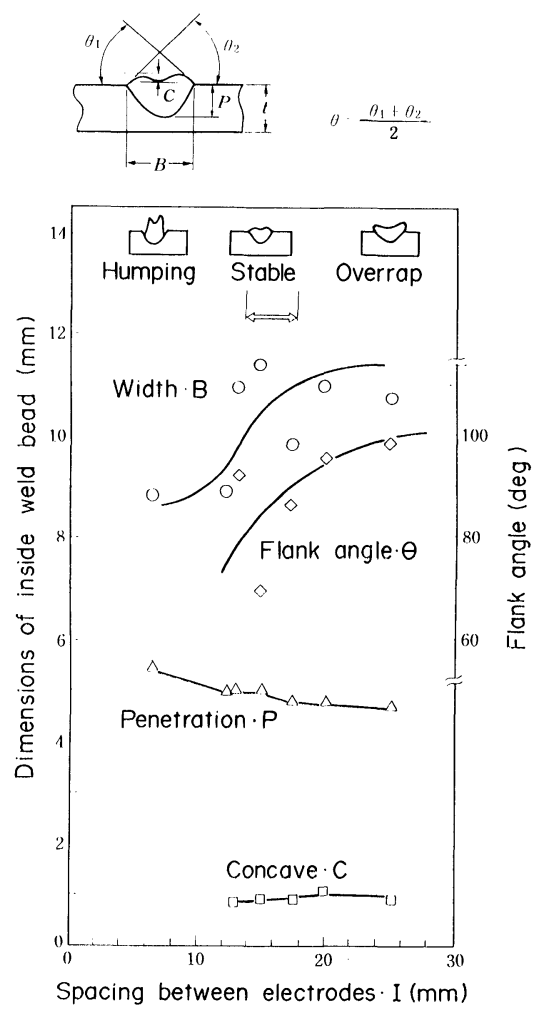

Fig. 13. Effect of spacing between electrodes on weld shape.

all pipe thickness.

At the present, welding speeds have been made higher through all pipe thickness as shown in Fig. 14.

\section{Conclusion}

The high speed welding in the spiral welding process was realized by the studies as follows;

1) studies of welding conditions such as current, arc

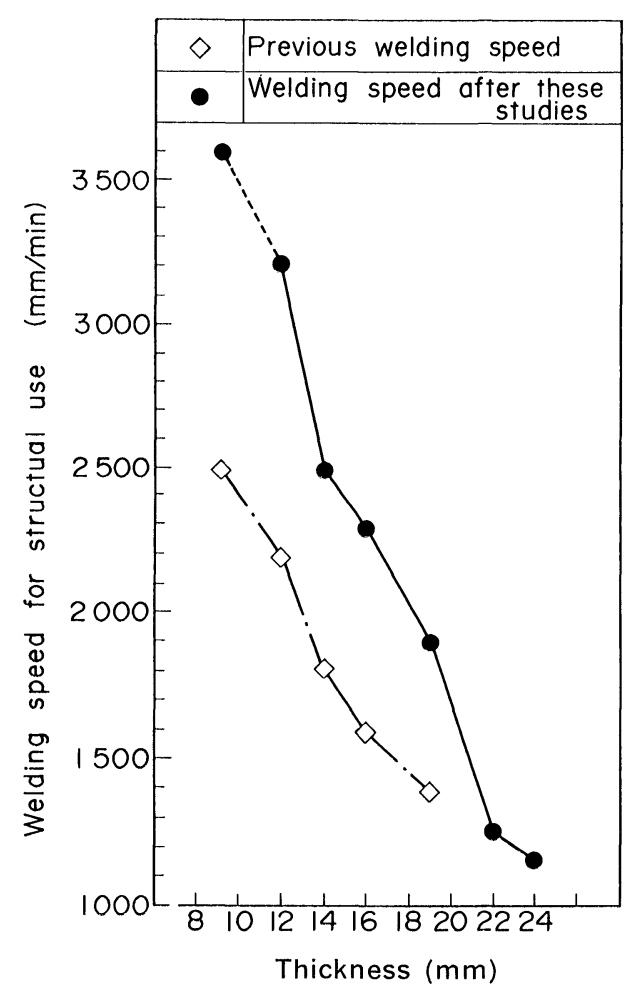

Fig. 14. Improvement of welding speed. (Applied for pipe in sizes $16 \mathrm{in.}$ and lager O.D.)

voltage, electrode position and spacing

2) development of flux for high speed welding.

\section{REFERENGES}

1) K. Akahide, T. Ukebe and K. Agusa: Preprints of the National Meeting of J.W.S., (Autumn, 1971), 181, (in Japanese).

2) K. Mori: J. Japan Inst. Metals, 36 (1967), 603. 